\title{
Maddikerne ud af lyrikken
}

\section{Af-tantrificering og genfortryllelse i N.F.S. Grundtvigs salmer}

\author{
KATRINE FRØKJÆR BAUNVIG
}

\begin{abstract}
ENGLISH ABSTRACT: Hymns written by N.F.S. Grundtvig (1783-1872) are conspicuously lacking in worms and in the smell of death. This fact is particularly striking when Grundtvig's texts are compared with the textual universe of Thomas Kingo (16341703). Grundtvig's hymns conformed to contemporary trends: Just as Danish public authorities during the first three decades of the $19^{\text {th }}$ century cleansed church buildings of decaing bodies and bones, Grundtvig carried out a similar cleansing of Danish church poetry. In order to capture these tendencies I have constructed the term 'de-tantrification'.
\end{abstract}

DANSK RESUME: I N.F.S. Grundtvigs (1783-1872) salmer er der en påfaldende mangel på orme og ligråd. Det bliver ikke mindst tydeligt $i$ hans syn på og bearbejdelse af Thomas Kingos (1634-1703) lyrik. Grundtvigs salmedigtigning, som viste sig levedygtig dvs. populær, tilpassede sig ændringer $i$ de renhedsforeskrifter, der styrede dødekulten $i$ hans samtid: På samme måde, som man i de første årtier af 1800-tallet fjernede lig fra danske kirkebygninger og større byer, fjernede Grundtvig dem fra den mest slagkraftige religiøse lyrik, salmerne. Denne bevægelse kalder jeg i denne artikel for 'af-tantrificering'.

KEYWORDS: N.F.S. Grundtvig; Thomas Kingo; hymns; tantrism; de-tantrification; death; cemeteries; modern Christianity; re-enchantment

\section{Indledning}

Lig er forfærdende. De udløser sorg og vækker afsky (Malinowski 1954, 29-35); de forstyrrer kognitive forventninger til menneskekroppe som levende, tænkende væsener (Boyer 2001, 203-228); de lugter gruopvækkende sødt, selvom gruen synes betinget af sansekonteksten (McCorckle 2013, 381-386). Derfor er det ikke overraskende at dødekulte og begravelsesritualer er universelt forekommende: De løser problemer, 
som er presserende både rent praktisk og eksistentielt. Mere overraskende er til gengæld de mange tendenser som dette nummer af Religionsvidenskabligt Tidsskrift omhandler. Miserabilistiske tendenser, ${ }^{1}$ der forsøger at holde fast i synet på livet som et forstadie til døden og på opfattelsen af verden som en kirkegård, og som derfor kan anspore enkeltindivider til at indsmørre sig i gravaske eller til at skrive digte fulde af skeletter og råd.

Som den amerikanske religionsforsker Robert N. Bellah har understreget, gjorde de miserabilistiske tankemåder, der slog igennem i aksetiden i det første årtusinde før vores tidsregning, op med forudgående arkaiske forståelser af livet og verden. Før den aksiale skepsis anså man verdensindretningen for at være fundamentalt god og hensigtsmæssig (Bellah 1964, 2011). Men med de aksiale bevægelser gav enkelte, skønt stærkt opmærksomhedstiltrækkende, personer og grupper af mennesker altså udtryk for en anden holdning, og asketer søgte nu udfrielse og frelse fra det jordiske liv ved på forskellig vis at undertrykke selvopretholdelsesbehov. Nogle levede i ekstrem ensomhed med stærkt begrænset adgang til mad og drikke. Andre kastede sig over aktiviteter, der bevidst-strategisk brød med etablerede renhedsnormer: Ved at bade i mudder, ved slet ikke at bade, ved at lade skægget stå osv. De øvrige temaartikler i dette nummer af Religionsvidenskabeligt Tidsskrift bugner af hinduistiske, buddhistiske, kristne, jødiske og muslimske eksempler på sådanne sammenkoblinger mellem forløsning og urenhed. Ligesom Hans J. Lundager Jensen og Marianne Schleicher er jeg tilbøjelig til at kalde denne sammenkobling 'tantrisk' (Lundager Jensen 2019, 19; Schleicher 2019, 106); sammenkoblingens udbredelse kalder jeg tilsvarende for 'tantrificering', mens jeg vil kalde den omvendte bevægelse - tilfælde af aktiv afkobling - for 'af-tantrificering'.

Hvor resten af dette temanummers bidrag er optaget af tantrificeringers mentale strukturer eller konkrete udtryksformer, vil jeg i stedet fokusere på tendenser til aftantrificering i dansk mainstream-kristendom i moderniteten, dvs. i tiden efter Den Franske Revolution. Dette kan ses hos N.F.S. Grundtvig (1783-1872), der som bekendt har spillet en afgørende rolle for dansk kristendom siden midten af det 19. århundrede. Nærmere bestemt skal det følgende dreje sig om Grundtvigs salmedigtning og dens påfaldende mangel på maddiker. Salmer er didaktiske tekster; de skrives ikke mindst som manualer til bekræftelse af normer, dogmer og verdensbilleder. Dette gælder også og i høj grad Grundtvigs salmer, som undertiden ligefrem antager karakter af mod-digtning til andre salmeforfatteres belæringer - ikke mindst til forgængeren Thomas Kingos (1634-1703). Kingos tekster er fulde af barok-tantrisme, af grave, dødningehoveder og orme. Hans salmer var stadig populære i Grundtvigs samtid. De indgik som et vigtigt element i den offentlige debat om kvaliteten af danske salmer, der fulgte på indførelsen af Evangelisk-kristelig Psalmebog til Brug ved Kirkeog Huus-Andagt i 1798 - en salmebog, som i fornuftens navn af-tantrificerede og afmytologiserede salmeteksterne.

'Miserabilisme' er den tyske filosof Peter Sloterdijks term for vedholdende tendenser til at tænke, tale og skrive menneskeheden og verden ned - en tendens som findes i mange varianter og på tværs af kulturer (2004, 699-711). For en introduktion se Lundager Jensen 2017, 22-25. 
I det følgende vil jeg vise, hvordan Grundtvigs egne salmer er et resultat af denne debat. Jeg vil for det første vise, hvordan han accepterede rationalismens af-tantrificering og indførte den i sin egen digtning. Dette bliver ikke udelukkende, men særligt tydeligt $\mathrm{i}$ hans syn på og bearbejdelse af Kingos salmer. For det andet vil jeg vise, hvordan Grundtvig omvendt gik imod rationalismens af-mytologisering: I et forsøg på at genfortrylle salmesangen og den kristne forestillingsverden oplivede han væsener og troper fra det kirkehistoriske og folkloristiske mytekatalog. Det vil sige, at nok lugede Grundtvig lig og orme ud af salmerne; men han forsøgte samtidig at finde plads til Phønix-fugle, Satan og andre virtuelle virkelighedsfigurer.

For at forstå det kulturelle grundlag for Grundtvigs af-tantrificering er det imidlertid nødvendigt først at se på det generelle syn på døde kroppe i hans samtid.

\section{Ejendomsbegravelserne ud af kirkerne, ligene ud af byen}

Begravelsesskikke hører til blandt de mest stabile i menneskelige kulturer (Brown 2015, 24). Så meget desto mere interessant er det, at en væsentlig udvikling i synet på døden og på afdøde menneskers kroppe fandt sted i vestlige kulturer generelt og Danmark specifikt fra midten af 1700-tallet til ind i sidste tredjedel af 1800-tallet - den periode, som den tyske begrebshistoriker Reinhart Koselleck peger på som en kulturel overgangsperiode, en 'Sattelzeit' (2003). Lig blev i stigende grad opfattet som ting, der skulle håndteres efter andre principper end de hidtil gældende. Først i sidste halvdel af 1800-tallet kunne man videnskabeligt påvise de farer, der hænger sammen med at begrave døde på steder, hvor levende mennesker dagligt opholder sig. ${ }^{2}$ Men allerede op gennem 1700-tallet skærpedes ubehaget ved "symbiosen" mellem levende og døde (Sommer 1998, 114), der ellers havde løbet som et dybt spor i de kristne kulturer frem til oplysningstiden.

Den religiøse legitimering af denne tantriske symbiose kan siges at have været et afgørende kendetegn for kristendommen, siden den fandt en stabil organiseringsform i senantikkens vestromerske rige. Her fik biskopper held med at kanalisere den righoldige energi, som strømmede i den udbredte privatpraksis for sammenkomster og festligheder ved familiegravsteder i nekropoler og ved martyr- og helgengrave, over i kirkelige rum: Som noget nyt flyttede man mange steder de døde ind i eller i nærheden af kirkerne, og depositio ad sanctos (begravelse nær en hellig genstand, bygning eller person) blev et efterstræbelsesværdigt princip (Brown 2015, 24-35). Gennem hele middelalderen gravlagde man således folk i eller ved de religiøse bygninger (Laqeuer 2015, 115). 'Kirke' var en betegnelse, der ikke var forbeholdt bygningerne, men som omfattede hele det grundstykke, som kirkebygningen lå på, og langt hovedparten af befolkningerne blev anonymt gravlagt på kirkegårdene, som var placeret centralt i byerne (jf. Baschet 2006, 390). Men grupper med indflydelse og penge kunne

2 Denne viden, som præciseredes af Louis Pasteur og aktualiseredes af koleraepidemier, førte til talrige sanerings- og anlægsprojekter (Osterhammel 2009, 314-321), men også til oprettelsen af ligbrændingsforeninger i vestlige lande samt en hæftig diskussion af denne praksis i de offentlige debatter (Prothero 2001). 
i middelalderen begrave deres døde individuelt og inde i selve kirkerummet, i stenkister under gulvet eller i dyre sarkofager placeret i et sidekapel. I renæssancen og den tidlige moderne periode fik det europæiske borgerskab også mulighed for at gravlægge døde inde i kirken. ${ }^{3}$ De øverste befolkningslag i 1400-1600-tallet gav endvidere gravmæleudsmykningen et "enormt opsving" (Sommer 2003, 29 et passim). Her fik både de efterladte familier og de afdøde selv mulighed for at iscenesætte sig som velhavende, veldannede og fromme (jf. Bach-Nielsen 2012). Selve udsmykningens flittige brug af knogler og kranier var for sin del præget af den overordnede miserabilistiske lyst til at træde ud af verden, som dominerede kulturen og kunsten, hvor memento mori var et refræn.

Med oplysningstiden ebbede denne lyst ud. Trangen til at flytte de døde væk fra helligstederne og fra de levendes verden voksede sig stærkere op gennem 1700-tallet (jf. Baschet 2006, 390-391; Laqeuer 2015, 271 et passim). Danske myndigheder blev påvirket af initiativer i andre europæiske lande, og i årene omkring århundredeskiftet skred man til handling: Allerede i de reformivrige 1780'ere pålagde kong Christian d. 7. landsbykirkegårdene at få bragt deres forhold i orden (Kragh 2003, 158). Men med et kongeligt cirkulære d. 22. februar $1805 \mathrm{blev}$ det fremover forbudt at foretage såkaldte ejendomsbegravelser, det vil sige begravelser inde i danske kirkebygninger. De lig, der allerede fandtes i kirkerummene, skulle man endvidere uskadeliggøre:

Da Kongen ikke finder det sømmeligt, at Bygninger, indviede til det Høieste Væsens Dyrkelse tillige afbenyttes som Giemmesteder for Legemer, der overgives til Forraadnelse; og da den fra mindre oplyste Tider nedarvede Skik, at begrave de Døde i Kirkerne, ofte har haft farlige Tilfælde, endog Helbreds Tab for de Efterlevende, til Folge; Saa opfordres Han til, at foreskrive saadanne Regler i Henseende til Brugen af de i Kirkerne allerede værende Btgravelsessteder [sic], at disse kan giøres uskadelige; i det Han drager Omsorg for, at Templerne i Hans Riger herefter kan vorde forbeholdne deres egentlige Bestemmelse.

Den traditionelle begravelsesskik forekom altså myndighederne at være sundhedsskadelig. Men først og fremmest blev den fremstillet som et brud på religiøst baserede renhedskategorier: Ligstank passer ikke sammen med gudsdyrkelse. ${ }^{4}$ Derfor måtte ligene ud på kirkegårdene, og i de større byer skulle de helt væk fra det daglige liv, hvorfor "enhver Kiøbsted-Kirke, gom [sic] ikke har Kirkegaard udenfor Byen, i det seeneste inden 2 Aar erholder en beqvem Plads til samme, af saadan Størrelse, som efter Menighedens Folkemængde er tilstrækkelig" . ${ }^{5}$

I årene efter 1805-forordningen intensiverede man desuden kravene til systematiseringen af driften af landets kirkegårde. Disse krav indskærpedes i et cirkulære fra august 1813, og man skulle nu i øget omfang 1) registrere de begravede, 2) tilse at

3 I Paris fra 1600-1640 opførte man eksempelvis hele 40 klosterkirker for at tilfredsstille et ønske i det katolske borgerskab om at stede sine døde til hvile i sådanne kirkerum (MacCulloch 2004, 475-476).

4 Lovteksten giver mulighed for balsamering af lig i kapeller, hvis forholdene er således, "at ingen Stank paa nogen Maade derfra kan indtrænge i Kirken"(Betænkning vedrørende Revision af Begravelsesloven og Ligbrændingsloven, 1973, bilag 3, stk. 5).

5 Betænkning vedrørende Revision af Begravelsesloven og Ligbrændingsloven, 1973, bilag 3, stk. 9. 
selve gravenes udformning og størrelse overholdt fastsatte mål, 3) sørge for, at kreaturer ikke græssede på landsbykirkegårdene, og 4) sørge for at vedligeholde gravene, så de ikke faldt sammen eller afslørede indholdet. Myndighederne fandt det nødvendigt at lægge eftertryk på disse regler: Forsømte man dem, kunne det udløse en bøde (Kragh 2003, 157-161).

I de større byer stillede disse påbud indirekte nye krav til omfanget af kirkegårdene. Sammenlagt med en vis befolkningstilvækst ${ }^{6}$ førte dette til oprettelsen af de såkaldte assistenskirkegårde: selvstændige hjælpekirkegårde, der placeredes uden for de tætbefolkede bykerner uden tilknytning til nogen bestemt kirke, og hvis opgave var at aflaste de gamle gårde, der oftest lå i tilknytning til en kirke (Jantzen 2006, 40). På længere sigt fik dette den konsekvens, at et stort antal begravelser flyttede helt væk fra kirkerne og ind i kapellerne på de nye kirkegårde. ${ }^{7}$

Et tidligt eksempel er Assistens Kirkegård i København, der i 1760 blev anlagt på en mark på det nuværende Nørrebro, omkranset af en mur. Ved århundredeskiftet fandt man det imidlertid nødvendigt at sætte porte op for at holde folk ude om natten. Tilsvarende blev der udstedt forbud mod salg og indtagelse af mad og drikke, fordi kirkegården havde udviklet sig til et sted for, hvad man opfattede som upassende forlystelser (Helweg 2010, 121).

Ideen bag disse forbud og de førnævnte cirkulærer synes at være, at de dødes verden skulle bringes i orden, og at den ikke skulle blandes (for meget) sammen med de levendes. Når det imidlertid ikke kunne undgås, skulle det ske under kontrollerede forhold og i dagslys, underforstår teksterne, som blev til i en periode, hvor angsten for gravrøvere, skindød og genfærd havde gode vilkår (Bourke 2005, 29-33; Kragh 2003, 31-49). Det er velkendt, at gruopvækkende forestillinger om de døde satte deres præg på samtidens rædselslitteratur (se fx Neill 2018), men, ser vi, altså også på bureaukrati og bysanering.

En af forklaringerne på denne udvikling kan måske findes i den betydning, man begyndte at tillægge erinderingerne om sine døde i denne periode. I sin klassiske gennemgang af faseskiftene i dødens mentalitetshistorie i Vesten fra middelalderen til moderniteten, giver den franske historiker Philippe Ariés det lange 19. århundrede overskriften 'la mort de toi' ('din død'). ${ }^{8}$ Hans tese er, at hvor familiemedlemmers død i tidligere tidsrum var en trist uomgængelighed, udviklede dødsfald i den nære familie sig til en absurditet, en skandale, som fremkaldte intense følsesmæssige sorg-

6 For en oversigt over udviklingen af befolkningstallet i Danmark de sidste 150 år, se Plovsing og Borchsenius 2000, 7 .

7 I 1918 ved udgangen af det lange 19. århundrede kunne Emma Gad således slå fast, at begravelser i kirkegårdens kapeller "nu er de almindeligste" (Gad 1994, 228).

8 De forudgående faser er den tidlige og højmiddelalderens afklarede 'et moriemur' ('og vi skal dø') og 'la mort de soi' ('min egen død'), som med afgørende variationer strakte sig fra 1200-tallet frem til begyndelsen af 1700-tallet - muligvis med 1500-1600-tallet som en art højdepunkt. Interessant er det, at overgangen fra et fokus på individets egen til den elskedes død kan registreres på gravstensinskriptioner. I den tidlige moderne periode taler den døde selv på stenen (Bach-Nielsen 2012). Fra romantikken og fremefter er det mere almindeligt, at de efterladte på stenen foreviger deres savn af den døde. 
tilstande i det 1800-tal, der helligholdt kernefamilien (Ariés 1974, 59). Denne udvikling udtrykte sig som omfangsrige tilbygninger til den gældende sorgetikkette (ibid., 55-82): I den detaljerigdom, der gjaldt for individers påklædning, når de havde mistet en slægtning; i højtideligholdelsen af begravelsesritualer; i udformningen af ligtaler; i nekrologers superlativer; i antallet af dødedigte. I forlængelse kan man opfatte det sådan, at liget skulle gemmes langt væk, så mindet om den afdødes liv, væsen og gerninger kunne stilles til skue og holdes ved lige. Døden er de levendes problem, mener Norbert Elias $(2001,3)$ - et særligt stort problem i denne periode, synes der at være tegn på. I hvert fald flyttede man ligene ud af kirkerne og ud af de større byer.

Men den levende befolkning fulgte på paradoksal vis efter de døde. Idealerne for de nye kirkegårde var præget af 1700-tallets landskabs- og havekunst (Dümpelmann 2016, 17-21; Laqueur 2015, 238 et passim; Sommer 2004, 47-60), ligesom forventningerne til adfærden under ophold på dem var påvirket af romantikkens trope, vandringsmanden, der i det fri kontemplerer livets store spørgsmål (Sommer 2004, 7582). Kirkegårde, i hvert fald metropolkirkegårde, skulle altså være æstetisk-pittoreske oplevelser, hvor byens borgere kunne gå rundt og for en stund komme i kontakt med sig selv, naturen og slægshistorien (Sommer 2003). Derfor blev det efterhånden et problem, hvis også disse nye områders funktion som gravplads blev alt for synlig.

I ugebladet Politievennen, ${ }^{9}$ der udkom fra 1798-1848 og optrykte patriotisksindede københavnerborgeres beklagelser over uorden og lovbrud i storbyen, ser man talrige eksempler på problemer på kirkegården. Et særligt detaljeret eksempel trykkes under overskriften "Nogle Spørgsmaal betræffende Gravernes Behandling af vore Dødes Been" i nr. 707 fra "Løverdagen den 18de Julii 1829", s. 468-470:10

Det er ikke sjældent at se, naar en ny Grav graves, hvor før har været begravet, at man opkaster store og smaa Menneskebeen ganske skødesløst med Jorden, og lader disse ligge, til Væmmelse og Harme for de Spadserende, og dem, der som Liigfølge er nødte til at træde ganske nær disse Menneskets sidste, forstyrrede Levninger.

Spadserende opfattede altså knogler som ulækre og malplacerede, når de lå oven mulde i slutningen af 1820'erne. De var upassende og makabre indslag på spadsereturen og til begravelsen. Var denne væmmelse et resultat af, at borgerskabet havde tillagt sig en ny vane med at benytte kirkegården som rekreativt område? Sandsynligvis ikke. En sådan funktion har både større og mindre byers kirkegårde haft før denne periode. Der synes heller ikke grund til at antage, at antallet af synlige knogler var i vækst. Mere nærliggende er det at foreslå, at der her er tale om, at myndighedernes ubehag ved lig i kirkerne efterhånden overtages af byborgerskabet (jf. Lützen 1998, 51-57), ${ }^{11}$ som forstærker ubehaget og spreder det til domæner også uden for kirkebygningerne.

Under denne fremstilling gemmer sig Mary Douglas' velkendte defintion af urenhed som "matter out of place" (Douglas 1984, 41). Den udvikling, jeg har skitseret

9 Links til samtlige scannede originaler findes på https://bibliotek.kk.dk/politivennen

10 https://issuu.com/nielsandersen/docs/politivennen1829_hft55

11 Trangen til orden og forskønnelse på kirkegården var dog ikke alene et storbyfænomen. I Svanninge anerkender embedsmænd i 1830 en tiltagende lyst blandt beboerne "til at hædre de Afdødes Minde ved paa bedste Maade at pynte deres Grave" (citeret i Kragh 2003, 161). 
overfor, mener jeg med andre ord bør forstås som et skred i de renhedskategorier, der styrerede dødekulten i Danmark fra sidste halvdel af 1700-tallet og ind i 1800-tallet, hvor de døde kroppe flyttede ud af kirkerne og ud af storbyen: Her skulle de forblive langt nede i jorden.

Det er måske en af årsagerne til, at de døde kroppe ikke kun flyttede ud af kirkernes sarkofager, mure og gulve, men også ud af den mest afgørende kristne lyriske udtryksform, salmerne - $\mathrm{i}$ hvert fald hos den salmeforfatter, der kom til at præge moderne dansk kristendom mest, N.F.S. Grundtvig. Dette bliver, som jeg vil vise i det følgende, ikke mindst tydeligt $\mathrm{i}$ hans syn på og bearbejdelser af forgængeren Thomas Kingos digtning.

\section{Dejlig er jorden}

Grundtvig var mere interesseret i livet før end efter døden; han repræsenterede en kristendom, der anerkendte livet og jorden som noget grundlæggende godt. Dette kan opfattes som et opgør med det stærke tantriske døds- og lidelsesfokus, som har haft stor, men varierende betydning for vestlig kristendom siden dens fremvækst i antikken. Selv Jesus' liv og voldsomme død insisterede Grundtvig på, at man måtte betragte som en fortælling om "det glædeligste og lykkeligste Menneske-Liv", der kan tænkes (Holm 2009, 227).

Glæden tilværelsen og dens omgivelser er ikke mindst tydelig i hans omtrent 1600 salmer. Teksterne er fulde af jordiske ting og væsener: Lærker, blomster, lindetræer, bøgeskove, ${ }^{12}$ siv, dug, strande, himle, skyer, torden, lyn, stjerner og sole; morgengry og aftenrøde, middags- og nattestunder; tunger, stemmer, sang, hjerter, hænder, smil og øjne - omgivelser, situationer og kroppe, som hans læsere kunne forventes jævnligt at befinde sig i, og som Grundtvig vel at mærke ikke opfordrede dem til at træde ud af. Tværtimod er denne lyrik en "ydmyg genkendelse" (Wigh-Poulsen 1991, 71) og ærbødig fejring af jorden og livet som guddommens skaberværk: Et "Sang-Offer", der stiger fra "Læber til Himlen" (Grundtvig 1825a, 4). På dette punkt har Grundtvigs salmer indlysende træk tilfælles med den arkaiske lovsang i GT - arkaisk i den betydning, som den førnævnte religionsforsker Robert N. Bellah har mættet begrebet med i sine teorier om religion og kulturel evolution $(1964,2011)$.

I forbifarten er det relevant at bemærke, at Grundtvig i modsætning til visse strømninger i moderne teologisk refleksion fra 1700-tallet og fremefter - strømninger, der, særligt siden oplysningstidens underminering af de gammeltestamentlige teksters ophavshistorier understreger forskellen mellem de to teksters status - ikke så noget kvalitativt skel mellem NT og GT (Høgenhaven 2011, 66 et passim; Holt 1996, 78). At denne omstændighed samtidig er udtryk for Grundtvigs såkaldt 'Mageløse Opdagelse', der fik ham til at opprioritere det folkelige menighedsfællesskab karakter og

12 Grundtvig valgte stof til sin lyrik, som skulle komme til at indgå i den nationale digtning. Inge Adriansen har skitseret fx lærkens $(2003,396-400)$ og bøgens $(2003,385-388)$ råderum som afgørende nationale symboler i det 19. og 20. århundrede. 
historie på bekostning af Bibelens status - dvs. NT og GTs samlede position - bliver for omfattende at udfolde her. ${ }^{13}$

Det afgørende er her, at tyngdepunktet og interessen i Grundtvigs salmetekster overvejende hviler på jorden, som "har en selvstændig betydning" (Grell 1980, 36). Selv efterlivet tænker Grundtvig i jordiske termer, oftest som en rar have, der vækker sommerferieminder (Wigh-Poulsen 1996). Igen og igen benytter han ordet ‘Guds-Haven' om efterlivet, ikke mindst i sine eksistentielle salmer om døden og i sine eskatologiske salmer om tiden efter Jesu genkomst (Scharling 1950). Haven som edensk og bibeldyb reference er åbenbar og langt fra enestående som dødsbillede i kristendommens historie: McDannell og Lang viser, hvor afgørende en rolle paradishaver og rosengårde spillede i middelalderlige og renæssanceideer om livet efter døden (2001, 70 et passim; 112-124). Samtidig hører man i Grundtvigs begrebsbrug et ekko af Martin Luthers pædagogiske forestillinger om jordens restaurering og renselse efter dommedag, hvor himlen og jorden skal blive et nyt Paradis (ibid., 152).

"Lykken svæver over Urte-Gaarden", kunne Grundtvig skrive i et af sine mange havedigte. Dette fokus på haven foldede sig senere ud som en særlig interesse for hortikultur i de grundtvigske miljøer i sidste halvdel af 1800-tallet (Waage Rasmussen 2006, 186-202, jf. Bach-Nielsen 1996). I Grundtvigs eget univsers kom den jordnære have som paradisvision til at skygge for den overjordiske lyshimmel, der har været hovedkonkurrenten til havebilledet i den kristne forestillingsverden; den empyreiske lys- eller ildhimmel har stået stærkt siden skolastikken (McDannell \& Lang 2001, 80 et passim). Det gør den ikke hos Grundtvig. Godt nok er der masser af lys i hans tekster; men det er langt oftest et sollys - ganske vist et kraftfuldt, helligt sollys, men ikke desto mindre ét, som er interessant, fordi det stråler ned på jorden.

Jordens særstatus i Grundtvigs verdensbillede har desuden konsekvenser for hans holdning til og forestillinger om et andet ontologisk domæne med en lang kristen brugshistorie: helvede (jf. Bremmer 2009). Helvede optræder ikke ofte; men når Grundtvig endelig vender sin opmærksomhed imod stedet, understreger måden, hvorpå han gør det, på eksemplarisk vis hans dedikation til det dennesidige. I afsnittet nedenfor om Grundtvigs genfortryllelser vil jeg fylde argumenter på denne påstand. For nærværende er det vigtigst at slå fast, at det jordnære i Grundtvigs billeder ikke fører til, at den guddommelige sfære svinder ind i hans fremstilling på samme måde, som den gjorde det $i$ hans samtids rationalistisk-deistiske kristendom. Det vil sige: som den gjorde det i Evangelisk-kristelig Psalmebog, der rettede sig mere mod den intenderede modtagers livssituation end mod himlen (Hammerum 1998, 172-182).

I Grundtvigs tekster vinder menneskenes verden netop mening og fylde i kraft af den guddommelige verden: "uden dig / tomt er alt på Jorderig", skriver han i salmen "Kom, Gud Helligaand, kom brat!" fra 1837 og underforstår, at jorden netop ikke er tom. Den er sværmende fuld af liv, væsener og mening. Undertiden rækker guden ligefrem sin "straalende Haand [...] fra Himmelen til Jorderigs Muld" og understreger forbindelsen mellem de to sfærer.

13 Mange har skrevet om Grundtvigs forhold til Luther. Ikke desto mindre bør Anders Holms arbejde fremhæves. For en introduktion til netop dette moment i Grundtvigs tænkning se artiklen “Grundtvigs Lutherbilleder" (Holm 2017, 27-33). 
Mange har før bemærket den stærke forbindelse mellem det jordisk-menneskelige og det himmelsk-guddommelige i Grundtvigs tænkning. ${ }^{14}$ Den viser sig da også utallige steder i hans tankeverden. Men for denne artikel, der udkommer i samme nummer af Religionsvidenskabeligt Tidsskrift som Hans J. Lundager Jensens "Den tanatologiske transformantion: Fra Sheol til Helvede", er det oplagt at fremdrage Grundtvigs lyriske bearbejdelse af den gammeltestamentlige historie om Jakobs drøm i Betel (Gen. 28, 10-22). Også og ikke mindst fordi Jakob var "en af Grundtvigs nøglepersoner" og denne fortælling var en, han vendte tilbage til gang på gang (Mikkelsen 1994, 125).

Følger man bibeltekstforlægget, løber historien i grove træk således: Jakob er på en rejse og har lagt sig til at sove med en sten som hovedstøtte under den åbne himmel på et sted, som ikke nærmere beskrives, da han i et drømmesyn ser Guds engle gå op og ned ad en himmelstige og dernæst med ét også Gud, som taler til ham. Jakob vågner og udbryder rædselslagen: "Hvor er dette sted frygtindgydende! Det er jo selve Guds hus, det er himlens port!" (Gen 28, 17). Netop Gen 28,10-22 benyttes af forskere som emblematisk for den gammeltestamentlige opfattelse, at der mellem menneskenes og den guddommelige verden er en logisk-naturlig afstand, en ontologisk differens. Derfor falder det ikke Jakob ind at forsøge at kravle op ad stigen (jf. Lundager Jensen 2019, 8-9); derfor bliver han grebet af frygt over, uvidende om dets status, at have opholdt sig på stedet.

I Grundtvigs version af fortællingen fra Sang-Værk til Den Danske Kirke-Skole er afstanden og derfor frygten imidlertid bemærkelsesværdigt underbetonet. ${ }^{15}$ Hos ham går historien således: Uden betænkninger lægger Jakob sig træt til at sove "Under aaben Himmel" med en "Steen til Hovedgiærde". Månen skinner, stjernerne blinker, englene synger sødt og Jakob lægger sig “med Bøn til Ro" og sover straks trygt “i Himlens Ly". Alt ånder med andre ord fred, naturen er venlig og passer på Jakob (Mikkelsen 1994, 125-127), da han får et drømmesyn "fra Gladhjems Vang". Han ser "Engle-Vrimlen", der som "Lynild" farer op og ned af stigen. For enden af stigen "Straaler [...] Alle Kongers Konge". Hans stemme lyder som “Orgel-Toner", og han siger "frygt kun ei" og forklarer Jakob, at han skal blive stamfader til "Stammer trindt paa Jorden". Et fantastisk og overvældende syn. Men hverken uhyggeligt eller traumatiserende. Da "Røsten tav og Synet svandt" gribes Jakob da heller ikke af spontan rædsel i Grundtvigs udlægning. Han bliver godt nok "forbauset" og har svært ved at "udstamme: Underfuldt er Stedet her, At vor Herre var saa nær, Det jeg ikke vidste."

14 To retninger skal fremhæves. Den ene undersøger Grundtvigs antropologi med afsæt i det teologiske begreb 'gudbilledlighed': Her er konsensus, at Grundtvig lægger vægt på kontinuiteten mellem det guddommelige og det menneskelige, samt at han givetvis er blevet påvirket af den græske kirkefader Irenæus til denne holdning (Thaning 1953; Thomsen 1983). Den anden angår en række studier i Grundtvigs kærlighedsbegreb, ikke mindst undersøgelser i Grundtvigs syn på sammenhængen mellem den himmelske og den jordiske kærlighed, mellem agape og eros - et sammenhængsfokus, der gerne fremhæves som teologisk nytænkning (Nyborg 2013; Heggem 2005. 2007).

15 Skønt den bibeloversættelse, Grundtvig kan formodes at have stiftet bekendtskab med (til trods for, at han sandsynligvis parafraserede efter erindring), ikke underspiller Jakobs gru: "Og hand frygtede, og sagde: hvor forferdelig er denne sted! Denne er ikke andet end Guds huus, og denne er himmelens port"(Gen. 28,17). Oversættelsen findes i 1780-bibeloversættelsen tilgængelig på: https://rex.kb.dk. 
Men bange bliver han først et stykke tid efter oplevelsen, da tankerne stimler sammen i "hans Hjerne". Angsten ryster han imidlertid hurtigt af sig. I den tidlige morgen indvier han sit hovedgærde "med Olje fin", og til trods for at han ikke har sovet meget om natten, er han frisk og "flux [...] paa-færde": Han begiver sig "Haabefuld i Herrens Navn" videre på sin vandring, endnu mens lærken synger "Mildt i morgenrøden".

Mellem menneskenes og 'den anden verden' er der, kan man udlede af teksten, en tosporet forbindelse, der på den ene side gør det relevant for mennesker at sende ord til guddommen (Jakob beder aftenbøn), og på den anden side gør det muligt for Jakob (og med ham menneskeslægten som sådan) at tappe håb og energi af sit møde med guden. Og selvom der ikke er noget "Spring, som sjeldnere lykkes end det fra Jorden til Himlen" (Grundtvig 1825b, 157), er det ikke umuligt at komme derop, det kræver blot en "Himmel-Stige" (ibid.): "den underlige Tone-Stige", som salmesangen bygger (ibid.) i konkrete situationer.

Denne pointe er væsentlig, hvis man ønsker at tegne en skitse af Grundtvigs verdensbillede, som det træder frem i hans lyrik, for netop denne antagelse om en stærk forbindelse gør det oplagt for ham at granske den jordiske vrimmel af liv. Derfor skriver digteren, at det "Poetiske hos Mennesket kundgør sig i Attraa efter, ved det Jordiske at erindres om det Himmelske" $(1812,122)$. Det er forbindelsen mellem himmel og jord, der inviterer Grundtvig til at tænke med de forhåndenværende ting og bruge dem i sine tekster.

Sangene og salmerne kan forstås som et forsøg på at begribe strukturerne i verdensmylderets forhold til det guddommelige. Med andre ord kan teksterne opfattes som en art hermeneutisk systematiseringsprojekt, hvoraf der fremtræeder et arkaiskpositivt verdensbillede. "Deilig er Jorden" ikke kun ifølge B.S. Ingemann, som i 1850 skrev salmen ved samme navn, men også ifølge hans ven og kollega N.F.S. Grundtvig. "Deilig er den Himmel blaa" havde Grundtvig da for længst skrevet og fortsat "Lyst det er at se derpå", så man ikke var i tvivl om, at det var det jordiske perspektiv, der for ham var det afgørende.

\section{Ormene ud af lyrikken}

Jorden er dejlig, og det "dennesidige liv er langt at foretrække" (Auken 1998, 141). Der er ikke noget "saliggørende ved at dø", mente Grundtvig (ibid.). Døden "med sin Istaphaand" var godt nok et tema, han vendte tilbage til i sine tekster - i ligtaler og mindeord, i digte og afhandlinger. Men det var først og fremmest døden som en kraft og som et beklageligt grundvilkår for de levende, der optog ham (jf. Høirup 1954): At tage ordentlig afsked med livet, det er "tungt at nemme", som han skrev i salmen "At sige Verden ret farvel" fra 1843. Men selvom døden er tilstede som et uungåeligt faktum, er der ikke mange tantriske træk ved Grundtvigs salmer. Han dvælede ikke ved graven som forgængeren Thomas Kingo (1634-1703). Kingos hovedinspiration var med Grundtvigs ord "Herrens Storværk, Død og Pine" (Grundtvig 1873, 365). Samme vurdering er indfældet $i$ indexet til den seneste monografiske Kingo-behandling, hvor 
man finder ord som 'blod', 'Carravagio, (Michelangelo Merisi)', 'melankoli','pønitense', 'tidsel' og 'tåreoffer' (Nielsen 2010, 528-546).

Grundtvig følte sig forpligtet på Kingos lyrik og anså ham for at være den danske kirkes "Asaph" - salmedigter og leder af de levitiske tempelsangere i GT. Grundtvig havde sunget Kingos sange siden sin barndom og roste dem for at være hjertevarme og billedskabende:

Kingo har sin Styrke i en levende Opfattelse og høitidelig Fremstilling af Bibel-Historien, og, med eet Ord, i det simpelt Høitidelige, som bør være det Herskende i Bede-Huset for alle Folk, og som dog i vore Dage falder selv de største Skjalde vanskeligt at ramme. (Grundtvig 1828, 32).

Hertil kom, at Grundtvig forsvarede den gamle Kingos salmebog ${ }^{16}$ i debatten om Evangelisk-kristelig Psalmebog til Brug ved Kirke- og Huus-Andagt (1798) - en debat, der er af så afgørende betydning for det øvrige, at jeg her må kile en nødtørftig skitse ind i fremstillingen:

Evangelisk-kristelig Psalmebog var frugten af et projekt igangsat af den sjællandske biskop (og Grundtvigs onkel), N.E. Balle (1744-1816). I de sidste årtier af 1700-tallet var forholdet mellem kristendom og oplysning et varmt emne i dansk presse. Et sent, men godt eksempel herpå er ugeskriftet Jesus og fornuften, som 1796-1801 var under ledelse af oplysningsmanden og teologen Otto Horrebow (1769-1823), der kæmpede for at udbrede opfattelsen af kristendommen som "den eeneste, evige, sande Fornuftens Religion" og som det eneste rigtige udgangspunkt for udviklingen af menneskers individuelle lykkefølelser. I dette miljø begyndte teologer og kirkelige embedsmænd at efterspørge tidssvarende salmer, som kunne "udtrykke glade følelser" (Kjærgaard 2003, 152-153). Det var sådanne strømninger, der i 1790 havde fået Balle til at nedsætte en kommission til udarbejdelsen af en samling, der kunne appellere til tiltagende mere kirkekritiske og individualiserede byborgerskabskristne. For at imødekomme denne gruppe skrev man derfor nye tekster mættet med deisme og oplysningskristendom, ligesom man rensede gamle tekster for myter, overtro og metafysik. Men denne udgivelse mødte modstand på landet. Her opfattede man de nye salmer som fortænkte, deres ordvalg for moderne og deres mytologiske univers for snævert. Med andre ord: Man beklagede sig altså over en afmytologisering, der fx førte til "at djævelen helt var forsvundet fra salmebogen" (Kjærgaard 2003, 165). I Jylland, ikke mindst i kredse præget af de gudelige vækkelser, fastholdt man Kingos salmebog; på Sjælland, hvor man indførte den ny og samtidig afgav retten til at genindføre den gamle, måtte man nøjes med at længes efter Kingos tekster.

At landbefolkningen på Sjælland faktisk længtes, og at den nye Evangelisk-kristelig Psalmebog burde have "laant mere af den Gamle" $(1807,190)$, var et omkvæd i Grundtvigs indlæg i debatten og i efterrefleksionerne årtier senere. For ham tjente de to bøger respektivt som eksempler på, hvordan man effektivt kan henholdsvis "udmale Billeder og udtvære Tanker" (Grundtvig 1828, 21). Den rationalistiske og moraliserende salmebog havde måske "Fortrin især med Hensyn paa Korrekthed i Versebygningen"

16 Kingos Salmebog er den populære forkortelse af Dend Forordnede Ny Kirke-Psalme-Bog fra 1699; Kingo havde skrevet 85 af bogens 300 salmer. 
(ibid.); men den havde ingen narrativ kraft eller evne til at gøre bibelske historier relevante "i en beskuelig Fortælling" $(1812,348)$. Denne evne havde Kingo. Derfor undrede det Grundtvig, at ikke én af Kingos salmer blev "optaget uforvansket" i den ny udgivelse (ibid.). Det var ikke selve omskrivningen, der var et problem. Enhver tradition bør undgå nostalgi og løbende tilpasse sig skiftende tidsånder, mente Grundtvig: "Støvskikkelsen af hedenfarne Tider, som af hedengangne Folk, er kun en Skygge, som Aanden vel kan svæve over med Ossianske Klagetoner, men ei oplive og besjæle!" $(1828,5)$. Eller med andre ord: Hvis man vil have en levende sangtradition, må man holde den tilpasningsdygtig og aktuel. Men man bør omvendt undgå at tilpasse sig for meget. Det var, hvad Evangelisk-kristelig Psalmebog havde gjort sig skyldig i at løbe ifølge Grundtvig. Han anså den for at være resultatet af en kirkelig elites fejlslagne analyse. For at indordne sig, hvad han kaldte en spidsborgerlig smag, havde man udpint indholdet for fortællinger og sætningerne for aktører og handlinger (ibid.). Herved havde man blot fremmedgjort sit egentlige bagland, den landbefolkning, der nu ikke var i stand til at læse de nye, mere besværlige salmetekster og som blev rørt til tårer, når de hørte "Kingos Høitids-Psalmer", som de kunne udenad (ibid.) - lød Grundtvigs kritik (jf. Balslev-Clausen 1983, 9-14).

Det er en kendt sag, at Grundtvig forsøgte at gøre, hvad han mente ikke var lykkedes i 1790'erne: Han kastede sig ud i et salmefornyelsesprojekt. Resultatet taler et indirekte, men klart sprog om hans syn på salmedigtningen: Den er ikke blot en himmelstige, der binder jord og himmel sammen, men også en 'dødsrige-stige' til at skabe forbindelse mellem generationer af kristne, dvs. mellem døde og levende. Under arbejdet med det, som blev til Sang-Værk til den danske Kirke (1837), ${ }^{17}$ skrev Grundtvig i et brev til B.S. Ingemann, at han forsøgte at smelte "Toner fra alle Hovedgangene $\mathrm{i}$ den almindelige Kirke" sammen (S. Grundtvig 1882, 198). I det første bind af sangværket er 59 af de 401 salmer så tydelig genbrug, at Grundtvig fandt det nødvendigt at udstyrre teksterne med en note. I disse noter står der 'efter', 'af', 'omarbeidet', 'sammenføiet', 'frit oversat' og 'fordansket'. Det var de gammeltestamentlige Davidssalmer, "Gammel-græske" salmer, lantinske "Pindse-Sange", Kædmon, "En Engelsk Daabs-Sang", Martin Luther, Hans Thomesen, H.A. Brorson og B.S. Ingemann osv., som Grundtvig bearbejdede - levn fra det, han kaldte 'de syv folkemenigheder'. Men omtrent halvdelen af disse noter angår en enkelt forgænger. 27 af de 59 signalerer Grundtvigs gæld til Kingo. Og hermed kommer vi tilbage til hovedsagen.

"Thomas Kingo er Psalmisten, i det danske Kirke-Kor", slog Grundtvig fast i SangVærk til Kirke-Skolen $(1873,365)$. Derfor ændrede han sjældent førstestrofen i de Kingosalmer, som han genbrugte. Ved at bibeholde indgangslinjen bibeholdt han værdien i den umiddelbare genkendelse. Men han ændrede meget andet. Der var nemlig elementer i Kingos digtning, som Grundtvig mente, at Evangelisk-kristelig Psalmebog med rette havde udeladt. Ting, han heller ikke selv "ville have med" (Stevns 1949, 19). Forgængerens tekster "behøvede en med Ærbødighed ændrende Haand" $(1812,347)$. Værst var hans bodssalmer (Grundtvig 1828, 33-36; Bach-Nielsen 2003, 94-95; Nielsen

17 De findes genoptrykt som bind $1.1 \mathrm{og} 1.2$ i fembindsudgaven Grundtvigs Sang-Værk, der udkom første gang på Det Danske Forlag fra 1944-1951 og igen på Gads Forlag 1981-1984. Jeg henviser her til sidstnævnte. 
2010, 328-330, 484-496). Grundtvig vidste godt, at Kingo havde skrevet dem, men ønskede at "han havde ladet det være" (Grundtvig 1828, 36). Det var netop den "patetiske Drivkraft" i fornægtelsen "af Verdenslivet som Tant" (Stevns 1949, 29), der er kondenseret i disse tekster, Grundtvig ikke brød sig om. Derfor er de ikke at finde blandt hans Kingo-salmer i Sang-Værk til den danske Kirke. Dem, han medtager, har titler som “Min Soel, min Lyst, min Glæde”, “O Jesu, søde Jesu, dig” og “Op, op med Himmel-Stemme".

En håndfuld år før Sang-Værk-arbejdet behandlede Grundtvig imidlertid nogle af disse særligt dystre og selvtugtige Kingo-salmer i en salmesamlingsudgivelse, der udkom i 1832 som Historiske Psalmer og Riim til Børne-Lærdom. I den forbindelse forsøgte Grundtvig at transformere Kingos dødsfokus, ligesom han forsøgte at få "Gravens Uhygge" til at forsvinde (Stevns 1949, 21). Det vil sige, at Grundtvig ad flere omgange lagde afstand til den tantriske ringeagt for kroppen, sanserne og livet på jorden, som var uomgængelig i Kingos digtning - den, som fik Kingo til at tage poetiske afskeder med livet; den, som fik ham til at interessere sig for nattens særlige morteficatio-potentiale (Bach-Nielsen 2003, 61-86); den, som lod forgængelighed og forfængelighed optræde som indlysende tvillingebegreber (Nielsen 2010, 355-366) nedenunder vers om døden og graven, hvor orme vrimler "i min Hud" og æder "Verdens Lyster ud."

På dette punkt indskyder jeg en præciserende parentes: At Kingos tantrisme er uomgængelig betyder ikke, at den er uimodsagt. Dobbeltheden i Kingos salmeunivers er indlysende. Sorrig og glæde vandrer til hobe i dette kompromisforsøg på at kombinere det aksiale udstiger-perspektiv med arkaiske livsopretholdende principper (Lundager Jensen 2019, 25-26). Grundtvig anerkendte ham da også som paradoksalt “Rig paa Smil igennem Taare" (Grundtvig 1873, 365).

Ikke desto mindre: Kingo levede i en nedgangstid. At Europa var i nedgang i det 17. århundrede, får man bekræftet $\mathrm{i}$ alt fra bredspektrede historiske studier (fx de Vires 2009, Trevor-Roper 1959) til wikipedia-opslag. Grundtvig var også indforstået hermed, ligesom han var indforstået med, hvilket præg sådanne omstændigheder kan sætte på befolkningers mentalitet: I Til Fædrenelandet om dets Tarv og Fare. Et Ord fra 1813 skriver han eksempelvis således: Jo

trangere Tiderne ere, jo mindre lysteligt Jordlivet tilbyder, jo uvissere, jo mere farefuldt det sees at være, desmindre adspredes Tankerne, desmindre beruses Sjælen, desmere hendrages Tanken til Døden og Graven $(1813,27)$.

I nedgangen mod år 1700, "hvor barokkens livsførelse med dens stærke farvning fra stoicismen" kastede "et smertelys over kristendommen" (Nielsen 2010, 21), udarbejdede Kingo salmebøger, som trænede enevældens befolkning i verdensforsagelse. Som Magnus Stevns opsummerede det: Kingos salmer skal ses som et opdragelsesarbejde, der gik ud på

at skabe oprigtig Foragt for Verden og dens Forfængelighed, saa Mennesket kan lære at hade den og i redelig Kamp for en sød og salig Ende hugge sig Vej frem mod den legemlige Død, der hjælper Sjælen ud af Kroppens usle "Ormesæk", saa den fri kan drage ad Himlen til (Stevns 1949, 25). 
Salmerne skulle få kristne i Danmark og Norge til at ramme dagen ind med morgenog aftensang - en ramme, der gav dem anledning til pønitense - det vil sige til at falde i alvorsfulde tanker, gøre dødsmeditationer og "udøse" suk. ${ }^{18}$ Sådan hedder det i fortalen til førstedelen af hans Andelige Siunge-Koor fra 1674, som var tænkt til privat andagtsbrug i modsætning til andenparten fra 1681, der var beregnet på kirkebrug. De "særdelis sukke" skylder folk sig selv, men først og fremmest kirken, kongehuset og almenvellet ("det gemene bestis") (Kingo 1674, 5-6). ${ }^{19}$ Sukkene udgør nemlig den energi, der sikrer landets fremgang. Salmesangen i hjemmene forvandler med andre ord private husstande til kraftværker for tantrisk baseret "floor og fremgang" og verdslig "Lyksalighed" (ibid.) ${ }^{20} \mathrm{i}$ denne post-reformatoriske logik, der søgte erstatning for middelalderens katolsk-monastiske "powerhouses of prayer" (Brown 2013, 219).

Sang spillede som sagt en afgørende rolle for sammenhængskraften mellem himlen og jorden og mellem de levende og de døde kristne ifølge Grundtvig. Og ligesom Kingo mente han, at de følelser, der vækkes ved at synge, havde en betydning for sammenhængskraften i nutidsfællesskaberne. Men til forskel fra Kingo lå han på linje med de oplysningstanker, der havde fået mændene bag Evangelisk-kristelig Psalmebog til at stræbe efter at kultivere glade følelser. I 1798 skulle salmerne oplive sangerne til dyd og samfundsharmoni ved at sørge for "Bekræftning og Forfremning" af sædelighed, orden, gavnlig virksomhed og uskrømtet menneskekærlighed $(1798,4)$. Grundtvig anså "Menighedens inderlige Deeltagelse" $(1828,31-32)$ i salmesangen for at være afgørende i opbyggelsen af fællesskabsfølelser (Baunvig 2013, 2014) - en opbyggelse, han baserede på tekster, hvor 'Lys' vandt over 'Grav', 'Smil' over 'Taare' og 'Liv' over 'Død'. ${ }^{21}$ Han efterspurgte triumf, glæde og jubel i salmerne. Det er en fejl og en hindring for kirken og fællesskabet, “Naar vore Salmer ej udtrykke den levende Følelse af, at vi ere overgangne fra Døden til Livet, have fundet det evige Liv i Guds Kjærlighed og drukket af hans Saligheds Kalk" $(1984,182)$. Tiden er løbet fra salmer, der kun udtrykker "Mindet om Guds store og underlige Gjerninger blandt Menneskenes Børn og Haab om Udløsning fra Forkrænkelighedens Baand"; salmer, der underspiller glæden ved jorden og livet som Kingos, kan ikke oplive fællessskaberne i 1800-tallet, mente Grundtvig (ibid., nn). “Gak, Ormesæk, og sov. Gud skal i morgen dig / vække her / men siden der / til liv evindeligt", 22 sukkede Kingo og forsøgte at se "kadavere,

18 En tradition for brugen af ordet 'suk' om bønner strækker sig tilbage til bibeltekster som Rom 8, 2226. Carsten Bach-Nielsen argumenterer endvidere for, hvordan Kingo-sukkene også har en forbindelse med den gammeltestamentlige offerrøg (2003, 36-37).

19 Teksten er tilgængelig på Arkiv for Dansk Litteraturs hjemmeside: http://adl.dk/solr_documents/kingo03val-workid54803\#kbOSD-0=page:4

20 Det er velkendt, at lykke og fremgang filtrede sig sammen til en tæt semantisk knude i den før moderne periode. En periode, som i bøger og på billeder pustede liv i den antik-romerske skæbnegudinde Fortuna (Bach-Nielsen 2003, 51-60; Brendecke og Vogt 2017; Sloterdijk 2013).

21 Denne konstatering læner sig op ad en heuristisk korpusundersøgelse, som kan efterprøves på Det Kongelige Biblioteks netlaboratorium, der i samarbejde med Grundtvig Centeret (AU) stiller ordfrekvensredskabet 'SMURF' til søgning i Grundtvis publicerede og digitaliserede tekster til rådighed på: https://labs.statsbiblioteket.dk/gruf/

22 "Den klare Soel gaar ned" fra 1674. 
hvor man naivt kunne se levende kroppe" (Lundager Jensen 2019, 25). Men for Grundtvig bestod øvelsen i det modsatte - også når han skrev om emner, det er svært at glædes over. I den førnævnte "At sige Verden ret farvel" insisterede han på at se en barnekrop, hvor der ligger et døende voksent menneske:

Før Døden med sin Istaphaand

Giør Skiel imellem Støv og Aand,

Bortvifter Hjertets Varme,

Indsove skal jeg da med Lyst,

Som Barnet ved sin Moders Bryst,

I dine Frelser Arme!

Om lige præcis denne Grundtvig-salme kan eller skal opfattes som aktiv og bevidst Kingo-moddigtigtning eller ej, er ikke det afgørende her. Det afgørende er den genrelle omstændighed, at afsmagen for Kingos orme træder fuldstændig så tydeligt frem i Grundtvigs lyrik, som vi har set, at væmmelsen ved lig i kirkebygninger og på storbykirkegårdene gjorde det $\mathrm{i}$ hans samtids lovtekster og offentlige debat. Med andre ord: I denne periode lagde nye renhedsforestillinger sig til rette, således at ligstank ikke længere passede sammen med gudsdyrkelse, hverken i konkret eller overført betydning, hverken i kirker, i salmebøger, aviser eller embedsskrivelser.

Madikker eller ej: Det var ligeså udfordrende for Grundtvig at se røde kinder som det var for Kingo at se ligblege. Alle virtuelle virkeligheder er svære at fastholde. De kræver træning og vedligeholdelse; salmegenren henter sin eksistensberettigelse i netop denne omstændighed. Det er min påstand, at Grundtvig havde en klar og intutiv fornemmelse for dette faktum. Dette afsløres ikke mindst i hans anerkendelse af, at Kingo løste salmeopgaven effektivt: Folk sang gerne hans billedmættede tekster med følelse og indlevelse. Men fornemmelsen afsløres også i Grundtvigs hovedkritik af Evangelisk-kristelig Psalmebog: Nok forsøgte den at træne befolkningen til et dydigt sindelag; men den leverede ingen billeder, ingen virtuel virkelighed, som kunne legitimere træningsprogrammet, og derfor tog befolkningen den ikke til sig.

\section{Grundtvigs genfortryllelser}

Grundtvigs forhold til Evangelisk-kristelig Psalmebog var ikke entydigt kritisk. Som jeg allerede har antydet, så han også positive træk ved projektet. Tillad en genopfriskning af de tre punkter, han værdsatte mest: For det første roste han holdet bag salmebogen for intentionen om at befri de gamle sange som Kingos for "vedhængende Særheder, som ere døde for os" (Grundtvig 1828, 32). Man skal ikke som katolikker hæge over relikvier: "Al kirkelig Skrin-Læggelse af Dødt, er Papisteri" (ibid.). De elementer, der virker smagløse og fremmedgørende på skiftende samtiders kristne, gør man derfor klogt i løbende at smide ud af salmebøgerne, var Grundtvigs adaptionistiske tankegang. For det andet roste han 1798-udgivelsen for at forsøge at skabe salmer, der på en ligefrem måde kan sætte ord på menneskers forhold ikke kun til Gud men også til "hinanden og de timelige Kaar", dvs. til de moralske, sociale og almenmenneskelig 
anliggender, som oplysningstænkere havde haft stort held med at udfolde (ibid.). Endelig og for det tredje fremhævde han som nævnt bogens "Korrekthed i Versebygningen" (ibid.); den mødte i hvert fald dele af samtidens præferencer.

Men disse roser havde torne. Lad os tage dem i omvendt rækkefølge: 3) Versebygningens korrekthed var først fremmest et udtryk for, at der var tale om en elitær "Kjøbstæds-Psalmebog", som forsøgte at stille en borgerlig smag tilfreds og udelod almuens ønsker samt læseevner af betragning (Grundtvig 1828, 32). 2) De i sig selv prisværdige oplysningsorienterede, sociale overvejelser stivnede i "moralske Læredigte", der var "enstonede, tørre og kolde" $(1811,180)$. De måtte ganske enkelt betragtes som golde og upoetiske paragraffer uden sans for historiens betydning: "Selv naar Moral og Fornuftsreligion skulle være Hovedgjenstanden for de kirkelige Sange" (ibid.), har de brug for historie. At Grundtvig vel at mærke ikke gerne så moral og fornuft som religiøse udgangspunkter, er i denne sammenhæng ikke så afgørende som pointen, der er, at selv fornuft og moral i et sådant tilfælde ville have brug for "den historiske Dragt" (ibid.) for at udbredes og rodfæstes. I denne dragt vævede Grundtvig historiens to betydningstråde sammen. Det var både 'historie', forstået som ophobede indsigter og tradition, og i betydningen mundtligt-narrative overleveringer, dvs. fortællinger, han sigtede til og mente manglede i Evangelisk-kristelig Psalmebog.

1) Rensningen og tilpasningen af de gamle salmer var gået for vidt, mente Grundtvig. Salmeteksternes persongalleri var blevet trimmet for handlende agenter. Der synes kun plads til et diffust øverste væsen, en almægtig gud. Det er på den baggrund, man må forstå Grundtvigs egne tekster. Disse tekster, der er mættede med agens, fungerer som en indirekte kritik af Evangelisk-kristelig Psalmebog på netop dette punkt. Grundtvigs tekster indeholder righoldige mængder af verber og subjekter, handlinger og væsener - ikke mindst fantastiske væsener som engle, phønixfugle og djævle. Hvor Evangelisk-kristelig Psalmebog aktivt forsøgte at afmytologisere, forsøgte Grundtvig at genfortrylle det kristne forestillingsunivers.

Denne beskrivelse er oplagt, hvis man ved 'genfortryllelse' forstår forsøg på at indarbejde fantastisk-magiske elementer i givne kollektive fiktionsformidlinger. Sådanne indarbejdelser er relevante i kulturelle miljøer, der er præget af det, Max Weber (1922) senere kaldte rationalisering og 'Entzauberung' ('affortryllelse'). Det vil sige miljøer som Danmark i 1800-tallet, hvor i hvert fald de uddannede dele af befolkningen havde givet afkald på visse traditionelle og gerne fantastisk-metafysiske forestillingers sandhedsværdi. Genfortryllelsesmomentet opstår ved, at de traditionelle forestillinger får en ny funktion; deres ontologiske status svækkes og de omformes til at være genstande for subjektive skønhedserfaringer og eksistentiel meningfuldhed. Dette peger på den ene side frem mod vor tids populærkulturelle dyrkelse af fantasygenren (jf. Davidsen 2017; Feldt 2017) og på den anden mod postmoderne filosoffers interesse for 'hyperrealisme' og 'simulacra' (jf. Friis 1987, 157).

Grundtvigs indarbejdelser af de overnaturlige og fantastiske elementer foregik hyppigst i tekster, han selv kaldte 'poetiske' eller 'historisk-poetiske'. Det kunne eksempelvis være omarbejdelser af norrønt-middelalderligt materiale som i hans behandlinger af kæmpeviser, dvs. folkeviser, der handler om guder og sagnhelte. Men 
det kunne også være udlægninger af mentalitetshistoriske udviklinger skrevet i prosaform. ${ }^{23}$ Genfortryllingen fik dog størst folkelig gennemslagskraft i de lyriske gendigtninger af det kristne traditionsstof, denne artikel først og fremmest angår: I salmerne.

Grundtvigs tiltag var på ingen måde enestående. Genfortryllelsesstrategier findes blandt mange af hans samtidige og de kan forstås som et romantisk fænomen i den brede, ikke-epokale forstand, hvormed Isaiah Berlin (2000) og Rüdiger Safranski har beskrevet romantikken (jf. Baunvig 2013, 30-39). Hvis romantikken er 'en fortsættelse af religionen med æstetiske midler’ som Safranski har foreslået (2007,392), er Grundtvigs behandling af det poetisk-kristelige fortællestof måske en fortsættelse af kristendommen med fiktionens eller den virtuelle virkeligheds midler.

Det er med afsæt i sådanne mellemregninger, man bedst forstår Grundtvigs kritik af Evangelisk-kristelig Psalmebogs tendens til at udviske eller helt ignorere domæner, der havde dybe rødder i den kristne forestillingsverden - dvs. tendensen til at følge det afmytologiserende program, som var en del af reformationsteologien. Undersøger man 1798-salmebogen, står det hurtigt klart, at Grundtvig havde ret i denne kritik.

Det er velkendt, at over- og underjordiske verdeners ontologiske status allerede i reformationsperioden var blevet svækket. Skærsilden forsvandt, mens himlens og særligt helvedes status blev påfaldende mere ustabil i de følgende århundreder. Denne udvikling bevægede sig med forskellige hastigheder i forskellige sociale lag. At himlens og helvedes svækkelse var stærkt fremskredet i det danske byborgerskab i årene omkring år 1800, fremgår af Evangelisk-kristelig Psalmebog. Her har 'Himmerig' tendens til at glide over i den psykologiske tilstand 'Salighed', og 'Helvede' samt dets hersker, 'Djævelen' og 'Satan', er næsten fraværende. ${ }^{24}$

Især Djævelens og helvedes status i oplysningssalmebogen interesserede Grundtvig, hvilket umiddelbart kan undre, når man tager hans overordnede af-tantrificerende tilbøjeligheder i betragtning. Ikke desto mindre ærgrede det ham, at begge dele var forsvundet. Uagtet

man tit i de gamle Psalmebøger med Grund kunde ønske lidt mindre om Helvede, og lidt meer om Himmerig, saa er det dog alt for latterligt at undsige Djævelen ved Daaben, som Kirkens og Christen-Livets farligste Fjende, og derpaa, under hele Kirkegangen, at lade, som han aldrig var til (Grundtvig 1828, 22).

Helvede og djævelene skulle altså ikke ikke udelades. Det var ikke en god løsning, når Evangelisk-kristelig Psalmebog erstattede djævle med eufemismer som “Mørkets frække Skarer" (ibid.). Man måtte afse lidt plads til djævle og helvede også i 1800tallets moderne kristendom, så der ikke blev tale om en "hovedkulds Overgang fra alt for meget til slet intet" (ibid.) for de dele af befolkningen, der skulle bruge salmebogen, men som ikke tidligere havde været tvunget til at forholde sig til den kristne

23 'Mentalitetshistorisk' er her min anakronistiske betegnelse for den pulje af Grundtvigs udgivelser, der beskæftiger sig med åndshistoriske tværsnit, som han undertiden kalder 'sindbilleder'. Det oplagte eksempel er Nordens Mythologi eller Sindbilled-Sprog historisk-poetisk udviklet og oplyst fra 1832.

24 I det 20. århundrede måtte både himmel og helvede affinde sig med være reduceret til symbolske referencer på eksistentielle tilstande i populær- og finkultur såvel som i universitetsteologi (McDannell og Lang 2001, 322 et passim; Baumann 1998, 63-72). 
elites affortryllede kristendom. Men det var ikke alene bratheden i udfasningen, der bekymrede Grundtvig: Ved at "ignorere Djævel og Helved" efterlod salmebogen sin bruger "hartad vaabenløs imod" (ibid.) de kræfter, de repræsenterede. Grundtvig mente ligefrem, at den "christelige Erfaring gennem Aarhundrede" demonstrerer, at de folk, som bevidst forsøger at undertrykke uhyggelige helvedshistorier vil være mere tilbøjelige til at få djævlene "paa Halsen" $(1828,23)$. Man må altså integrere disse ubehagelige elementer i det virtuelle univers som religiøst-psykologisk stabiliserende foranstaltninger, synes tankegangen at være. Men også, underforstår Grundtvig, fordi disse væsener og dette sted gennem sin lange kirkelige brugshistorie havde tilkæmpet sig plads i det kollektive forestillingsunivers. Denne plads kunne man mene, hvad man ville om, men man kunne ikke afvikle den. Derfor var det et problem for Grundtvig - den salmedigter, der selv helst digtede om haver og urtegårde og som forsøgte at undgå tantrisme og morbiditet - at Evangelisk-kristelig Psalmebog uartikuleret skrev helvede ud af historien.

Grundtvig skrev ikke selv meget om Helvede, men det, han skrev, var billedrigt og udpenslende. Det bedste eksempel er fra 1837 og står som nummer 243 i Sang-Værk til den danske Kirke: "I Kveld blev der banket paa Helvedes Port", en tekst som er skrevet efter forlæg af den angel-saksiske poet Kædmon, der levede i 600-tallet (jf. Brown 2015, 373-379). ${ }^{25}$ Selvom der er mørkt i tekstens helvede, som er et "svælgende Dyb", myldrer det med liv: Kryb, øgler, drager, djævle, ulve, ildsprudende bjerge, sovende fanger, hel-haner, genfærd, slanger, orme, Adam og Eva. De larmer: Der høres gråd, hyl, brag og fnysen, men alt dette ønsker "en Kæmpe", som nedstiger fra jorden, "at dæmpe!". Denne kæmpe har superkræfter. Han kan gå på gløder; han er så stor, at han kan trampe øgler og drager ihjel; han kan knuse hugorme og binde helvedsulve, “mens Afgrunden brager!”. Det er selvfølgelig Jesus Kristus, der er tale om. Efter sin korsfæstelse og begravelse er han på "Tredje-Dagen" draget til dødsriget ledsaget af en stor engleskare. Som "en Soel" oplyser han mørket. "I Helved skinned Guds Herligheds Glands", så meget, at de kulsorte djævle blev "Guldfarved". Lyset er så kraftigt, at det samtidig får mure til at revne og indgangsporten til at flyve af sine hængsler. I dybet lyder 'Guds søns' stemme som “Lærkens en Pindsedags-Morgen” og med hans besøg "fødtes i Helved den evige Trøst" og "Menneske-Sorgen" fik sit dødstød. I modsætning til Kædmon-forlægget fører helten hos Grundtvig en længere samtale med Eva og ikke Adam. ${ }^{26}$ Hun undskylder sin ur-synd: "Jeg ene det voldte, at vi ligge her, / For jeg lod mig daare, desværre!". Men hun gør Kristus opmærksom på, at han jo selv er "undfanget og født af en Kvinde" og beder ham om ikke at efterlade den moder, der falder ham "til Fod". Efter disse ord dannes der på underfuld vis en glorie med "deilige Farver i Krone-Gestalt" om Evas hoved: Så kyssede "Guds Herligheds Glands" sin moder og derefter tog han hende samt alle de andre døde mennesker med til himmels. "Triumph blev der nu, hvor kun Graad hørdes før, / Kun Død sad i Helved bedrøvet".

25 For en engelsk oversættelse af og nyttigt noteapparat til denne salme se S.A.J. Bradleys “Grundtvig and the Decent into Hell" (2018).

26 Om Grundtvigs påfaldende progressive syn på kvinder, som det går for vidt at udfolde her, se Lone Kølle Martinsens vigtige “Danmarks største Digterinde” (2017). 
I denne fortælling svækkes den ontologiske differens mellem de forskellige kosmologiske sfærer. Væsenerne i helvede får nu pludselig mulighed for at emigrere til himlen ved at følge Kristus-helten, der kommer fra jorden. Han er altså i stand til at ophæve ontologiske skel. Men for denne artikels overordnede emne er det først og fremmest interessant, at rømmelsen og dermed afmattelsen af helvede formuleres med påfaldende fortælleglæde og i en detaljemæssig højopløsning fuld af farver og monstrøse væsener. Billedet af helvede står med andre ord atypisk stærkt og klart for en 1800-talssalme. Ved at forpligte sig på efterklangene ${ }^{27}$ af den angel-saksiske og tidlige middelalderlige behandling af Jesus Kristus' nedfart til dødsriget, kan Grundtvig rehabilitere forestillingen om helvede som gyldigt opslag i det kristne mytekatalog, han er ved at opbygge. Men Grundtvigs genoprejsning af helvede er paradoksal: Den interesserer sig for helvede som forestillet, virtuelt sted, og den forudsætter indforståelse med, at jorden er den vigtige og reelle sfære.

\section{Tilpasningsdygtighed og relevant fiktion}

I Den Danske Salmebog fra 2002 er der ingen af de originale salmer udarbejdet til Evangelisk-kristelig Psalmebog medtaget; 81 er forfattet af Kingo. Derimod findes der 163 originale af Grundtvigs samt 90 af hans gendigtninger. Grundtvig har med andre ord skrevet eller omskrevet $32 \%$ af det samlede antal på 791 salmer. Det gør ham til langt den bedst repræsenterede forfatter i bogen. ${ }^{28} \mathrm{Ud}$ fra en selektionistisk logik synes Grundtvigs glade grundholdning og fiktionsbevarende stil altså at have vist sig mere tilpasningsdygting end, på den ene side, Kingos tantrisme og, på den anden, oplysningstidens affortryllede og agensforladte dogmevers.

På baggrund af undersøgelserne i denne artikel foreslår jeg, at man søger i hvert fald dele af forklaringen på Grundtvig-salmernes gennemslagskraft i hans flair for at aflæse den af-tantrificerende tidsånd. Hans salmer fandt sig til rette i omgivelser, hvor forholdet til ligstank havde ændret sig - i omgivelser, hvor den postreformatoriske ontologiske sammentrækning af verdensbilledet havde fået belønningsstrukturen for de tantriske elementer i den kristne dødekult til at kollapse. Formuleret på en anden måde: Grundtvigs tekster passede ind i et miljø, hvor den aksiale verdensforsagelse, den faste tro på himlen som udfrielsesmulighed eller helvede som trussel, var svækket. Derfor var det blevet svært at opretholde den kristne despositio ad sanctos-praksis, ikke mindst fordi den i udgangspunktet gik imod menneskelige basistilbøjeligheder til at sørge for skarp adskillelse af døde og levende kroppe - tilbøjeligheder, der som antydet synes at være både stærke og universelle (jf. Boyer 2001, 203218; McCorkle 2013).

27 De eksplicit intertekstuelle 'efterklangsdigte' er en vægtig genre i Grundtvigs forfatterskab. En genre, der kan forstås smalt og afgrænset som hos Flemming Lundgreen-Nielsen (1980, 664-665) eller som en bred strategi, der også griber ind i Grundtvigs salmedigtning. Den sidste læsning findes hos Anders Holm (2001, 31-32), som jeg her tilslutter mig.

28 Nummer to er H.A. Brorson, der optræder med 116 eller knap $15 \%$. 
Men hans salmer kunne mere end blot at tilpasse sig en tiltagende affortryllelse og afsmag for lig i kirkerne. De kunne sætte noget andet i stedet; de omplantede fantastiske og metafysiske elementer fra det kristne forestillingskatalog $\mathrm{i}$, hvad jeg drister mig til at kalde en 'relevant fiktion', ${ }^{29}$ hvilket er måske er det bedste mainstream religioner kan håbe på at blive i vores tidsrum? Et rum, der åbnede sig i Grundtvigs levetid, i romantikken.

\section{LITTERATUR}

Adriansen, Inge

2003 Nationale symboler i Det Danske Rige 1830-2000, Museum Tusculanums Forlag.

Ariés, Phillippe

1975 Essais sur l'histoire de la mort en Occident: du Moyen Âge à nos jours, Éditions du seuil.

Auken, Sune

1998 Eftermæle. En studie i den danske dødedigtning fra Anders Arrebo til Søren Ulrik Thomsen, Museum Tusculanum.

2014 "Gåden" Ved lejlighed. Grundtvig og genrerne, in: Sune Auken \& Christel Sunesen, eds., Spring, 276-302.

Bach-Nielsen, Carsten

1996 "Paradishave eller jammerdal? Vækkelsesbevægelserne og deres eftervirkninger", Har de en æstetik?, in: Gregers Algreen-Ussing, ed., De kulturelle bevægelsers brug og formning af byens og landskabets rum, Statens Byggeforskningsinstitut,19-37.

2003 Kingo CCC: Studier udgivet $i$ 300-året for digterens død, Anis.

2011 "Talende sten", Kirkegårdskultur, 78-89.

Baumann, Zygmund

1998 "Postmodern Religion?", in: Paul Heelas, ed., Religion, Modernity and Postmodernity, Blackwell, 55-78.

Baunvig, Katrine Frøkjær

2013 Forsamlingen først. N.F.S. Grundtvig og Émile Durkheims syn på frllesskab. Ph.d.-afhandling, Afdeling for Religionsvidenskab, Grundtvig Centeret, Aarhus Universitet.

2014 "Den inderlige deltagelse" Grundtvig-Studier nr. 65, 157-176.

Baschet, Jérôme

2009 La Civilisation Féodale. De l'an mil à la colonisation de l'Amérique, Flammarion.

Bellah, Robert N.

1964 "Religious Evolution", American Sociological Review, 358-374.

2011 Religion in Human Evolution. From the Paleolithic to the Axial Age, Belknap Press.

Bourke, Joanna

2005 Fear. A Cultural History, Virago.

Boyer, Pascal

2001 Religion Explained, Vintage.

Bradley, S.A.J.

2018 "The Decent into Hell", Grundtvig-Studier nr. 68, 95-106.

29 I denne formulering lyder et ekko af Dan Sperbers udtryk 'relevant mysteries' (1996 [1988], 73) og hans tanker om, hvorfor gådefulde eller tvetydige udsagn har en overlevelsesfordel i den kulturelle herunder religiøse selektionsproces. Om Grundtvigs forhold til gåder se Sune Aukens udfoldelse i artiklen "Gåden" (2014). 
Bremmer, Jan

2009 "Christian Hell: From the Apocalypse of Peter to the Apocalypse of Paul", Numen 56, 298-325.

Brendecke, Arndt \& Peter Vogt, eds.

2017 The End of Fortuna and the Rise of Modernity, De Greuter.

Brown, Peter

2015 The Cult of the Saints. Its Rise and Function in Latin Christianity, University of Chicago Press.

2013 The Rise of Western Christendom. Triumph and Diversity, A.D. 200-1000, Wiley-Blackwell [1996].

Davidsen, Markus A.

2017 "The Jedi Community: History and Folklore of a Fiction-based Religion", New Directions in Folklore 15, 7-49.

Douglas, Mary

1984 Purity and Danger, Routledge [1966].

Dümpelmann, Sonja

2016 "Introduction", in: Sonja Dümpelmann, ed., A Cultural History of Gardens. In the Age of Empire, Bloomsbury Publishing, 1-36.

Elias, Norbert

2001 The Loneliness of the Dying, Continuum.

Feldt, Laura

2017 "Contemporary fantasy fiction and representations of religion: Playing with reality, myth and magic in His Dark Material and Harry Potter", in: Markus A. Davidsen, ed., Narrative and Belief: The Religious Affordance of Supernatural Fiction, Routledge, 62-86.

Friis, Helmuth

1987 Den løse mening, Forlaget Anis.

Gad, Emma

1994 Takt og Tone: Hvordan vi omgaas, Gyldendal [1918].

Grell, Helge

1980 Skaberordet og billedordet. Studier over Grundtvigs teologi om ordet. Skrifter udgivet af GrundtvigSelskabet XVII.

Grundtvig, N.F.S.

1807 "Om Religion og Liturgie", Theologisk Maanedsskrift bd. 10, 129-201 (GV).

1811 "Hr. Sandsiger!", Sandsigeren no. 12, 179-187 (GV).

1812 Kort Begreb af Verdens Krønike i Sammenhæng, Seidelins Forlag (GV).

1813 Til Fædrelandet om dets Tarv og Fare. Et Ord, P.H. Høeckes Enke (GV).

1825 "[Anmeldelse af] Høimesse-Psalmer til Kirkeaarets Helligdage af B.S. Ingemann", Theologisk Maanedsskrift bd. 3, 156-162 (GV).

1828 "[Anmeldelse af] Psalmer og aandelige Sange af Thomas Kingo, samlede og udgivne af P.A. Fenger, Theologisk Maanedsskrift bd. 13, 1-36 (GV).

1873 Salmer og aandelige Sange. Sang-Vxrket til Kirke-Skolen, Karl Schønberg.

1984 Grundtvigs prædikener bd. 5 1832, Gad.

Grundtvig, Svend

1882 Grundtvig og Ingemann. Brevvexling 1821-1859, Samfundet til den danske Litteraturs Fremme.

Hammerum, Vibeke

1998 "Evangelisk-christelig Psalmebog af 1798. Et tilbageblik på et speciale", Hymnologiske meddelelser 27 (4), 165-182.

Hansen, Uffe

1937 Grundtvigs Salmedigtning. Dens Historie og Indhold. II, 1837-1850, Andelsbogtrykkeriet.

Heggem, Synnøve Sakura

2005 Kjærlighetens makt, maskerade og mosaikk. En lesning af N.F.S. Grundtvigs Sang-Værk til den Danske Kirke (1837), Oslo, Unipub.

2007 "Mennesket i verden som brud", Grundtvig-Studier nr. 58, 148-167. 
Helweg, Stine

2010 "Et kort rids af Assistens Kirkegårds historie", Assistens 250, Center for kirkegårde, 121-131.

Holm, Anders

2001 Historie og efterklang. En studie i N.F.S. Grundtvigs tidsskrift Danne-Virke. Odense Universitetsforlag.

2009 To samtidige. Kierkegaards og Grundtvigs kritik af hinanden, Anis.

2017 "Grundtvigs Lutherbilleder" in: Ove Korsgaard og Michael Schelde, eds. På afstand. Forskydninger mellem Grundtvig og Luther, Eksistensen Akademisk, 15-36.

Holt, Else K.

1996 "Stat op i gry, min Gud! Tre gammeltestamentlige salmer gendigtet af Grundtvig", GrundtvigStudier $n$ r. 47, 79-96.

Høgenhaven, Jesper

2011 "Grundtvig som fortolker af Det Gamle Testamente", Grundtvig-Studier nr. 62, 51-80.

Jantzen, Connie

2006 "Fra kirkegård til rådhuspark", Kirkegårdskultur, 41-50.

Koselleck, Reinhart

2003 "Über die Theoriebedürftigkeit der Geschichtswissenschaft", in: Zeitschichten: Studien zur Historik, Suhrkamp, 298-315.

Kragh, Birgitte

2003 Til jord skal du blive... Dødens og begravelsens kulturhistorie i Danmark 1780-1990, Skrifter fra Museumsrådet for Sønderjyllands Amt.

Laqueur, Thomas W.

2015 The Work of the Dead, Princeton University Press, 2015.

Lundager Jensen, Hans J.

2017 "Peter Sloterdijk, skum og religion", Religionsvidenskabeligt Tidsskrift, 5-37.

2019 "Igennem urenhed til himlen. Den tanatologiske transformation fra israelitisk religion til kristendom." Religionsvidenskabeligt Tidsskrift, 7-29.

Lundgreen-Nielsen, Flemming

1980 Det handlende ord I-II, København, Gyldendal.

Lützen, Karin

1998 Byen tæmmes. Kernefamilie, sociale reformer og velgørenhed i 1800-tallets København, Hans Reitzels.

MacCulloch, Diarmaid

2004 Reformation. Europe's House Divided 1490-1700, Penguin Books.

Malinowski, Bronislaw

1953 Magic, Science and Religion: And Other Essays, New York, Doubleday Achor Books [1948].

Martinsen, Lone Kølle

2017 "Danmarks største Digterinde", in: Katrine Frøkjær Baunvig og Micael Schelde, eds., Den gode, den onde. Om grundtvigianister og branditter,), Eksistensen Akademisk, 49-72.

McCorkle, William

2013 "From corpse to concept: a cognitive theory on the ritualized treatment of dead bodies", in: Armin Geertz, ed., Origins of Religion, Cognition and Culture, Acumen, 374-413.

Mikkelsen, Inger Lise

1994 "Hyrdeliv og paradisdrøm. Om Grundtvigs syn på hyrder", Grundtvig-Studier nr. 45, 122-141.

Nielsen, Erik A.

2010 Thomas Kingo. Barok, enevælde, kristendom, Gyldendal.

Nyborg, Ole

2013 Grundtvig og kærligheden. Kærlighedsforståelsen i N.F.S. Grundtvigs prædikener, Ph.d.-afhandling, Det Teologiske Fakultet, Københavns Universitet.

Osterhammel, Jürgen 
2009 The Transformation of the World. A Global History of the Nineteenth Century, Princeton University Press.

Plovsing, Jan \& Lars Borchsenius

2000 Befolkningen i 150 år, Danmarks Statistik.

Prothero, Stephen

2001 Purified by Fire - A History of Cremation in America, University of California Press.

Scharling, C.I.

1950 "Kristi genkomst og kødets opstandelse. Det eskatologiske hos Grundtvig", Grundtvig-Studier nr. 3, 7-58.

Schleicher, Marianne

2019 "Shabbedai Tsvis nedstingning til Farao - et jødisk eksempel på forløsning gennem urenhed", Religionsvidenskabeligt Tidsskrift 69, 105-119.

Schulz, Frieder

1976 Die Gebete Luthers. Quellen und Forschungen zur Reformationsgeschichte, Gütersloher Verlagshaus Gerd Mohn.

Sloterdijk, Peter

2004 Sphären III: Schäume. Plurale sphärologie, Suhrkamp.

2013 In the World Interior of Capital. For a Philosophical Theory of Globalization, Polity..

Sommer, Anne-Louise

1998 "De elysiske marker - 1800-tallets metropolkirkegård", in: A. B. Petersen \& A.L. Sommer, eds.,)Dødens rum, , Odense Universitetsforlag, 113-126.

2003 De dødes haver. Den moderne storbykirkegård, Odense, Syddansk Universitetsforlag.

Sperber, Dan

1996 Explaining Culture. A Naturalistic Approach, Blackwell [1988]

Stevns, Magnus

1949 "Grundtvig og Kingos salmer", Grundtvig-Studier nr. 2, 16-34.

Thaning, Kaj

1953 "Grundtvigs møde med Irenæus", Grundtvig-Studier nr. 6, 7-68.

Thomsen, Niels

1983 "Grundtvig i oldkirkens spejl", in: Christian Thodberg og Anders Pontoppidan Thyssen, eds., Grundtvig og grundtvigianisme i nyt lys, Aarhus Universitetsforlag, 197-209.

Trevor-Roper, H.R.

1959 "The General Crisis of the 17th Century", Past $\mathcal{E}$ Present 16, 31-64.

Vries, Jan de.

2009 "The Economic Crisis of the Seventeenth Century after Fifty Years", Journal of Interdisciplinary History vol. 40, 151-194.

Weber, Max

1922 "Rationaliserung, Fortschritt und Entzauberung der Welt", Wissenschaft als Beruf.

Wigh-Poulsen, Henrik

1991 "Digteren og Den Sandheds Aand. Grundtvigs helligaindsteologi og den engelske romantik", Grundtvig-Studier nr. 42, 71-88.

1996 "Barnet i haven - analyse af et grundtvigsk motiv og dets rødder i en tidlig litterær tradition", Grundtvig-Studier nr. 47, 58-76.

Katrine Frøkjær Baunvig, lektor, ph.d., Grundtvig Centeret, Aarhus Universitet baunvig@cas.au.dk 